\title{
Dicyemid fauna composition and infection patterns in relation to cephalopod host biology and ecology
}

\author{
Sarah R. Catalano ${ }^{1,2,3,4}$, Ian D. Whittington ${ }^{1,5}$, Stephen C. Donnellan ${ }^{1,3,4}$ and Bronwyn M. Gillanders , $^{1,2,6}$ \\ ${ }^{1}$ School of Earth and Environmental Sciences, University of Adelaide, North Terrace, Adelaide, Australia; \\ ${ }^{2}$ Southern Seas Ecology Laboratories, University of Adelaide, North Terrace, Adelaide, Australia; \\ ${ }^{3}$ Australian Centre for Evolutionary Biology and Biodiversity, University of Adelaide, North Terrace, Adelaide, Australia; \\ ${ }^{4}$ Evolutionary Biology Unit, The South Australian Museum, North Terrace, Adelaide, Australia; \\ ${ }^{5}$ Parasitology Section, The South Australian Museum, North Terrace, Adelaide, Australia; \\ ${ }^{6}$ Environment Institute, University of Adelaide, Adelaide, Australia
}

\begin{abstract}
Ten Southern Hemisphere cephalopod species from six families collected from six localities in western, southern and eastern Australia were examined for dicyemid parasites. A total of 11 dicyemid species were recorded, with three cephalopod species uninfected, four infected by one dicyemid species and three infected by multiple dicyemid species. Dicyemid species prevalence ranged from $24-100 \%$, with observed infection patterns explored due to host size, host life history properties, host geographical collection locality and inter-parasite species competition for attachment sites, space and nutrients. Left and right renal appendages were treated as separate entities and four different patterns of infection by asexual and sexual dicyemid stages were observed. The detection within a single host individual of asexual dicyemid stages in one renal appendage and sexual dicyemid stages in the other renal appendage supported the notion that developmental cues mediating stage transition are parasite-controlled, and also occurs independently and in isolation within each renal appendage. Our study exploring dicyemid parasite fauna composition in relation to cephalopod host biology and ecology therefore represents a thorough, broad-scale taxonomic analysis that allows for a greater understanding of dicyemid infection patterns.
\end{abstract}

Keywords: Dicyemida, Dicyema, Dicyemennea, renal appendages, Southern Hemisphere cephalopods, prevalence

For a parasite to infect a host species, it must be able to overcome environmental barriers in the habitat, biological barriers provided by the host and constraints imposed by its own life cycle (Roberts et al. 2002). As parasites are in close association with, and depend on their host, they are also closely associated with the ecological traits of the host (Whittington et al. 2000). Therefore, patterns of infection may be influenced by a range of factors associated with the host (e.g. host size, host geographical range and habitat, host life history properties, host age and host longevity). For highly host-species specific parasites, the challenge of initial infection is centered on recognising and infecting the correct host species in what may be a mixed community of hosts or else the life cycle may not be completed. It therefore seems for a parasite a generalist way of life would be preferable. However, specialisation may be advantageous especially if the host is not infected by any other parasite species so that competition for space, nutrients and resources is low. Additionally, restriction to one or only a few host species can benefit parasite fitness, as there is no need to adapt the structure of the attachment organ, the expression of digestive enzymes or the strategy to evade the immune response, which may otherwise be the case for a generalist parasite (Combes 1997).

Dicyemid mesozoan parasites (Dicyemida van Beneden, 1876) are small organisms found with high intensity in the renal appendages of benthic cephalopods (Furuya and Tsuneki 2003, Furuya et al. 2004). They are highly host-species specific, although co-infection by more than one dicyemid species in a single cephalopod species has been documented (Furuya 1999). These parasites are characterised by two stages of development (vermiform and infusoriform) and two modes of reproduction (asexual and sexual). While the asexual vermiform stages are restricted to the renal appendage of the host cephalopod, the sexually produced dispersal infusoriform stage, termed the 'infusoriform embryo', escapes from the renal appendages via the urine into the sea to find and infect a new host individual (McConnaughey 1951, Furuya et al. 2003). As cephalopods are short-lived (Semmens et 
al. 2007), escaping an older host is necessary to ensure survival and continuation of the dicyemid life cycle. For a complete review of the dicyemid life cycle, including information on reproductive traits and unknown processes, see McConnaughey (1951) and Furuya et al. (2003). In general, the infusoriform embryos are small, with an average length of 32-36 $\mu \mathrm{m}$, average width of 26-28 $\mu \mathrm{m}$ and average depth of 24-25 $\mu \mathrm{m}$, and do not survive for more than four days in seawater (McConnaughey 1951). Despite the dynamic challenges for infusoriform embryos of finding and infecting the correct host species with a limited life span in a large, fluid, ever-changing environment, dicyemid parasites are still found in almost all benthic cephalopods examined.

Currently, the majority of the research and knowledge on dicyemid parasites and their infection patterns is Northern Hemisphere oriented, with 97 of the 122 currently described species from Northern Hemisphere cephalopods. Here, we examine dicyemid trends and patterns of infection in relation to host biology and ecology for 11 dicyemid species recorded from seven Southern Hemisphere cephalopod species in four families collected across multiple geographical localities. Specifically, we explore the occurrence and prevalence of dicyemid species in relation to the following host characteristics: size, life history strategy and geographical collection locality. We also discuss observed patterns of infection by asexual and sexual dicyemid stages in left versus right renal appendages, presenting support for parasite-controlled developmental cues mediating the transition between asexual and sexual stages. Finally, we discuss the dicyemid life cycle with respect to the observed prevalence and infection patterns.

\section{MATERIALS AND METHODS}

\section{Cephalopod sampling and necropsies}

A total of 149 individual cephalopods comprising 10 species from six families were examined for dicyemid parasites. Individuals were collected from six localities in western, southern and eastern Australian waters via line fishing, SCUBA, snorkeling and from the by-catch of research prawn trawl surveys (organised by the South Australian Research and Development Institute and Western Australian Fisheries) from July 2010 to January 2013 (see Fig. 1). All cephalopods were examined fresh immediately upon capture, except for four giant Australian cuttlefish (Sepia apama Gray) individuals collected from the western Tasman Sea, New South Wales. These specimens were housed in tanks at the Cronulla Fisheries Research Centre for 2-3 months, and following natural death (S. apama is semelparous therefore death occurred 'naturally' in the tanks following reproduction), were examined for dicyemid parasites.

Cephalopod necropsies follow the methods outlined in Catalano and Furuya (2013), except that up to 16 smears per renal appendage were made for larger ( $>15 \mathrm{~cm}$ mantle length) host individuals. A host mantle tissue sample was collected from each individual and stored in $100 \%$ DNA grade ethanol. Each cephalopod individual was weighed and the mantle length (ML)

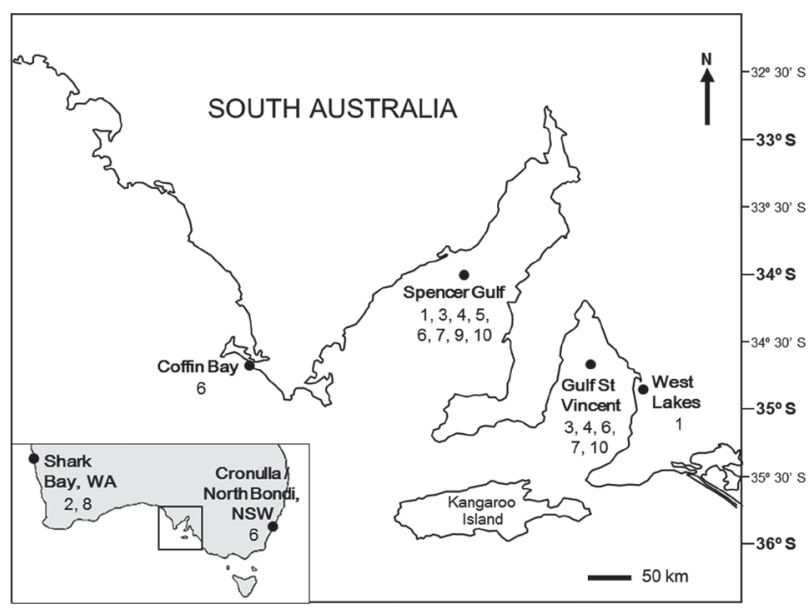

Fig. 1. Collection localities (black circles) for each cephalopod species (1-10) examined in this study from western, southern and eastern Australia. Abbreviations: 1 - Euprymna tasmanica; 2 -Metasepia pfefferi; 3 - Nototodarus gouldi; 4 -Octopus berrima; 5 - O. kaurna; 6 - Sepia apama; 7 - S. novaehollandiae; 8 - S. papuensis; 9 - Sepioloidea lineolata; 10 - Sepioteuthis australis; NSW - New South Wales; WA - Western Australia.

recorded, with ML measurements for Octopus spp. individuals following Norman and Sweeney (1997).

Smear preparations and examination of dicyemid morphological characters

Mayer's haematoxylin, Heidenham's iron haematoxylin, Ehrlich's acid haematoxylin and eosin 1\% alcoholic solution were trialed at various dilutions and staining times to determine the optimum for visualisation of dicyemid characters. Staining with Ehrlich's acid haematoxylin diluted 20 parts MilliQ water to 1 part stain for $20 \mathrm{~min}$, dehydration in an ethanol series and counterstaining in eosin $(70 \%$ ethanol for $10 \mathrm{~min}, 90 \%$ ethanol for $10 \mathrm{~min}$, eosin $1 \%$ alcoholic solution diluted 20 parts MilliQ water to 1 part stain for $2 \mathrm{~min}$ and $100 \%$ ethanol for 15-20 $\mathrm{min}$ ) provided the best contrast to compare morphological characters and was used in this study. Stained smears were mounted in Canada balsam and dried on a hot plate at $50{ }^{\circ} \mathrm{C}$ before examination with a compound microscope at magnifications up to $\times 1500$. The dicyemid fauna of each cephalopod species examined is presented in Table 1, including information on host collection localities, size range and dicyemid infection rates. Prevalence is expressed as a percentage and was calculated for each dicyemid species as the number of host individuals infected from the collection locality divided by the total number of host individuals examined from the collection locality. Low prevalence is defined as $1-33 \%$, medium prevalence as $34-66 \%$ and high prevalence as $67-100 \%$.

\section{Exploring host size variation}

The sampled ML range (synonymous with host size) for infected cephalopod species was divided into size groups of equal increments. The presence of dicyemid species in each size group was then recorded and plotted to evaluate patterns in dicyemid fauna composition by host size (Fig. 2). As only a single Octopus kaurna Stranks individual was examined, this species was not included. The ML ranges for Sepioloidea lineolata Quoy et Gaimard (45 mm), O. berrima Stranks et Norman ( $55 \mathrm{~mm})$, 
Table 1. Australian cephalopod species examined for dicyemid parasites, including associated dicyemid fauna, host collection localities, dicyemid infection rates and host size ranges $(\mathrm{mm})$. Type locality in italics for dicyemid species with multiple localities.

\begin{tabular}{|c|c|c|c|c|c|}
\hline Cephalopod species & Dicyemid species & Collection locality & $\begin{array}{l}\text { No. of } \\
\text { individuals } \\
\text { examined, } \\
\text { no. infected } \\
\text { (prevalence) }\end{array}$ & $\begin{array}{c}\text { ML range } \\
\text { (infected } \\
\text { ML } \\
\text { range) }\end{array}$ & $\begin{array}{l}\text { Refer- } \\
\text { ence }\end{array}$ \\
\hline \multicolumn{6}{|l|}{ Loliginidae Lesueur } \\
\hline $\begin{array}{l}\text { Sepioteuthis australis } \\
\text { Quoy et Gaimard }\end{array}$ & $\begin{array}{l}\text { Dicyema calamaroceum } \\
\text { Catalano et Furuya, } 2013\end{array}$ & $\begin{array}{l}S G\left(33^{\circ} 18^{\prime} 37^{\prime \prime S} ; 137^{\circ} 30^{\prime} 45^{\prime \prime E}\right), \\
\left.\text { GSV (35'16'12"S; } 138^{\circ} 09^{\prime} 10^{\prime \prime E}\right), \text { SA }\end{array}$ & $25,6(24)$ & $\begin{array}{c}75-205 \\
(90-160)\end{array}$ & 1 \\
\hline \multicolumn{6}{|l|}{ Octopodidae d'Orbigny } \\
\hline $\begin{array}{l}\text { Octopus berrima } \\
\text { Stranks et Norman }\end{array}$ & $\begin{array}{l}\text { Dicyemennea floscephalum } \\
\text { Catalano, } 2013\end{array}$ & $\begin{array}{l}S G\left(33^{\circ} 49^{\prime} 00^{\prime \prime} \mathrm{S} ; 137^{\circ} 16^{\prime} 29^{\prime \prime E}\right), \\
\text { GSV }\left(34^{\circ} 46^{\prime} 30^{\prime \prime S} ; 138^{\circ} 12^{\prime} 09^{\prime \prime E}\right), \text { SA }\end{array}$ & $22,22(100)$ & $\begin{array}{c}35-90 \\
(35-90)\end{array}$ & 2 \\
\hline $\begin{array}{l}\text { Octopus kaurna } \\
\text { Stranks }\end{array}$ & Dicyema sp.1 & $\mathrm{SG}\left(33^{\circ} 27^{\prime} 28^{\prime \prime S} ; 137^{\circ} 28^{\prime} 50^{\prime \prime E}\right)$ & $1,1(100)$ & $45(45)$ & ND \\
\hline \multicolumn{6}{|l|}{ Ommastrephidae Steenstrup } \\
\hline $\begin{array}{l}\text { Nototodarus gouldi } \\
\text { McCoy }\end{array}$ & uninfected & $\begin{array}{l}\left.\text { SG ( } 33^{\circ} 27^{\prime} 28^{\prime \prime S} \text {; } 137^{\circ} 28^{\prime} 50^{\prime \prime E}\right) \text {, } \\
\left.\text { GSV ( } 35^{\circ} 07^{\prime} 55^{\prime \prime S} \text {; } 138^{\circ} 13^{\prime} 32^{\prime \prime E}\right), \text { SA }\end{array}$ & $3,0(0)$ & $155-160$ & \\
\hline \multicolumn{6}{|l|}{ Sepiadariidae Fischer } \\
\hline $\begin{array}{l}\text { Sepioloidea lineolata } \\
\text { Quoy et Gaimard }\end{array}$ & $\begin{array}{l}\text { Dicyema pyjamaceum } \\
\text { Catalano et Furuya, } 2013\end{array}$ & 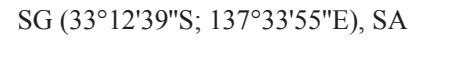 & $5,5(100)$ & $\begin{array}{c}95-140 \\
(95-140)\end{array}$ & 1 \\
\hline \multicolumn{6}{|l|}{ Sepiidae Leach } \\
\hline $\begin{array}{l}\text { Metasepia pfefferi } \\
\text { Hoyle }\end{array}$ & uninfected & SB (2522'01"S; $\left.113^{\circ} 37^{\prime} 26^{\prime \prime E}\right)$, WA & $2,0(0)$ & $40-50$ & \\
\hline \multirow[t]{4}{*}{$\begin{array}{l}\text { Sepia apama } \\
\text { Gray }\end{array}$} & $\begin{array}{l}\text { Dicyema coffinense } \\
\text { Catalano, } 2013\end{array}$ & 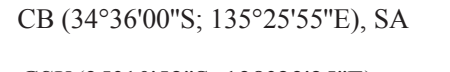 & $11,8(73)$ & $\begin{array}{c}95-495 \\
(117-207)\end{array}$ & 3 \\
\hline & $\begin{array}{l}\text { Dicyema koinonum } \\
\text { Catalano, } 2013\end{array}$ & 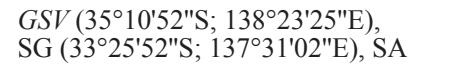 & $36,35(97)$ & $\begin{array}{c}95-495 \\
(95-215)\end{array}$ & 3 \\
\hline & $\begin{array}{l}\text { Dicyema multimegalum } \\
\text { Catalano, } 2013\end{array}$ & $\begin{array}{l}C R\left(34^{\circ} 04^{\prime} 20^{\prime \prime S} \text {; } 151^{\circ} 09^{\prime} 35^{\prime \prime E}\right), \\
\left.\text { NB ( } 33^{\circ} 53^{\prime} 22 " \mathrm{~S} ; 151^{\circ} 17^{\prime} 12^{\prime \prime}\right) \text {, NSW }\end{array}$ & $4,3(75)$ & $\begin{array}{c}95-495 \\
(380-495)\end{array}$ & 3 \\
\hline & $\begin{array}{l}\text { Dicyemennea spencerense } \\
\text { Catalano, } 2013\end{array}$ & 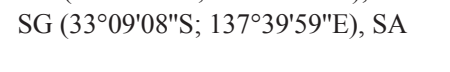 & $26,14(54)$ & $\begin{array}{l}95-495 \\
(100-215)\end{array}$ & 3 \\
\hline \multirow[t]{3}{*}{$\begin{array}{l}\text { Sepia novaehollandiae } \\
\text { Hoyle }\end{array}$} & $\begin{array}{l}\text { Dicyema koinonum } \\
\text { Catalano, } 2013\end{array}$ & 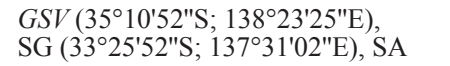 & $27,7(26)$ & $\begin{array}{c}55-120 \\
(55-120)\end{array}$ & 3 \\
\hline & $\begin{array}{l}\text { Dicyema vincentense } \\
\text { Catalano, } 2013\end{array}$ & GSV (3510'52"S; $\left.138^{\circ} 23^{\prime} 25^{\prime \prime E}\right)$, SA & $16,13(81)$ & $\begin{array}{l}55-120 \\
(75-105)\end{array}$ & 3 \\
\hline & $\begin{array}{l}\text { Dicyemennea spencerense } \\
\text { Catalano, } 2013\end{array}$ & 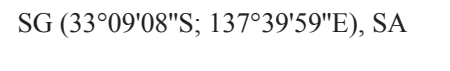 & $11,10(91)$ & $\begin{array}{l}55-120 \\
(81-120)\end{array}$ & 3 \\
\hline \multirow[t]{2}{*}{$\begin{array}{l}\text { Sepia papuensis } \\
\text { Hoyle }\end{array}$} & $\begin{array}{l}\text { Dicyema furuyi } \\
\text { Catalano, } 2013\end{array}$ & SB (2500'43"S; $\left.113^{\circ} 22^{\prime} 28^{\prime \prime E}\right)$, WA & $7,4(57)$ & $\begin{array}{l}95-170 \\
(120-170)\end{array}$ & 2 \\
\hline & $\begin{array}{l}\text { Dicyema papuceum } \\
\text { Catalano, } 2013\end{array}$ & $\mathrm{SB}\left(25^{\circ} 00^{\prime} 43^{\prime \prime S} ; 113^{\circ} 22^{\prime} 28^{\prime \prime} \mathrm{E}\right)$, WA & $7,7(100)$ & $\begin{array}{c}95-170 \\
(95-170)\end{array}$ & 2 \\
\hline \multicolumn{6}{|l|}{ Sepiolidae Leach } \\
\hline $\begin{array}{l}\text { Euprymna tasmanica } \\
\text { Pfeffer }\end{array}$ & uninfected & $\begin{array}{l}\left.\text { SG ( } 33^{\circ} 27^{\prime} 28^{\prime \prime S} ; 137^{\circ} 28^{\prime} 50^{\prime \prime E}\right), \\
\left.\text { WL ( } 34^{\circ} 53^{\prime} 13^{\prime \prime S} \text {; } 138^{\circ} 29^{\prime} 23^{\prime \prime E}\right), \text { SA }\end{array}$ & $6,0(0)$ & $9-32$ & \\
\hline
\end{tabular}

Size range indicates the mantle length (ML) range of host individuals sampled, with size range of infected individuals in parentheses; 1 - Catalano and Furuya (2013); 2 - Catalano (2013a); 3 - Catalano (2013b); ND - not described; CB - Coffin Bay; CR - Cronulla; GSV - Gulf St Vincent; NB - North Bondi; NSW - New South Wales; SA - South Australia; SB - Shark Bay, SG - Spencer Gulf; WA - Western Australia; WL - West Lakes.

Sepia novaehollandiae Hoyle (65 mm), S. papuensis Hoyle $(75 \mathrm{~mm})$ and Sepioteuthis australis Quoy et Gaimard (130 mm) collected in this study were divided into five groups and the ML range for Sepia apama $(400 \mathrm{~mm})$ was divided into 10 groups (Fig. 2).

\section{Exploring the patterns of infection in renal appendages}

The left and right renal appendages were examined as separate entities for each host individual, except where indicated otherwise. To distinguish between renal appendages: the left renal appendage was collected from the left side of the body of cephalopods placed ventral side up with the head facing towards the person performing the necropsy, and the right renal appendage was collected from the right side of the body of cephalopods orientated in the same manner. This was kept consistent for all cephalopod individuals examined. For infected host individuals, the presence/absence of life cycle stages observed from each re- nal appendage was then recorded. Nematogens and vermiform embryos were grouped and recorded as 'asexual stages', with rhombogens and infusoriform embryos grouped and recorded as 'sexual stages'.

\section{RESULTS}

\section{Cephalopod species infected and dicyemid species recorded}

Of the 10 species of cephalopods examined for dicyemid parasites in this study, seven were infected, namely three cuttlefish species (Sepia apama, S. novaehollandiae and S. papuensis), two squid species (Sepioloidea lineolata and Sepioteuthis australis) and two octopus species (Octopus berrima and O. kaurna) (Table 1). Di- 

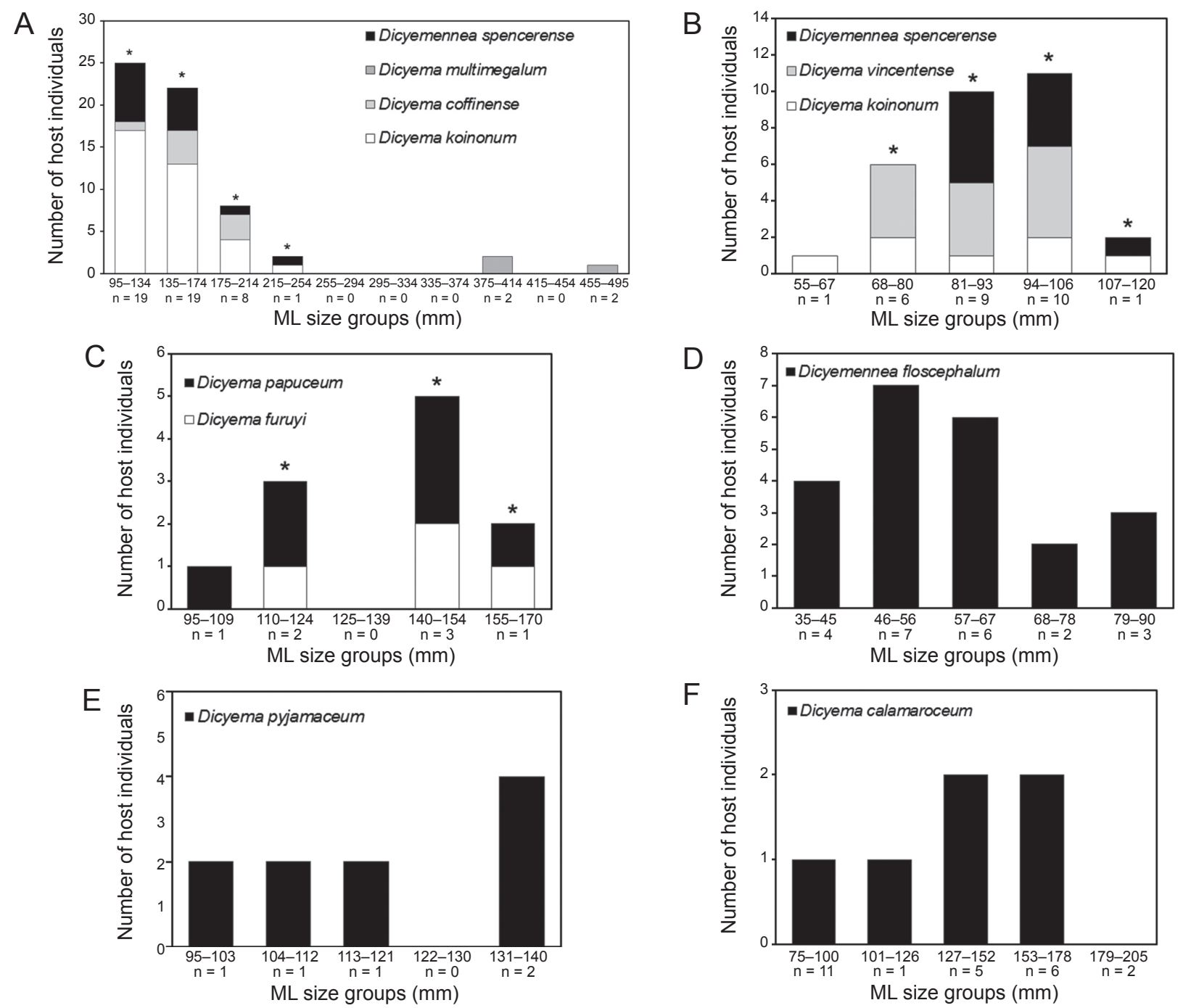

Fig. 2. The number of host individuals infected by each dicyemid species in each size group. Range presented is sampled ML range for each host species. A - Sepia apama; B - S. novaehollandiae; $\mathbf{C}-$ S. papuensis; D - Octopus berrima $; \mathbf{E}$ - Sepioloidea lineolata; $\mathbf{F}$ - Sepioteuthis australis. Abbreviations: $\mathrm{n}$ - the number of host individuals sampled in each size group, ${ }^{*}$ - host size groups with infection by multiple dicyemid species.

cyemids were not recorded from squid species Euprymna tasmanica Pfeffer and Nototodarus gouldi McCoy, or the cuttlefish Metasepia pfefferi Hoyle (Table 1). Four cephalopod species were infected by one dicyemid species, and three cephalopod species were infected by multiple dicyemid species.

In total, 11 dicyemid species were documented from two genera, with nine species of Dicyema von Kölliker, 1849 and two species of Dicyemennea Whitman, 1883 (Table 1). Ten of the 11 dicyemid species have been formally described (see Catalano 2013a,b, Catalano and Furuya 2013). As Dicyema sp. 1 (four metapolar cells opposite four propolar cells observed in smears) was only recorded from a single $O$. kaurna individual and infection did not include all stages in the dicyemid life cycle (rhombogens exclusively observed), this dicyemid species has not been described.

\section{Prevalence}

For infected host individuals from each collection locality, dicyemid species prevalence ranged from $24-100 \%$. Low prevalence (1-33\%) was recorded for Dicyema calamaroceum Catalano et Furuya, 2013 infecting Sepioteuthis australis (24\%) and D. koinonum Catalano, 2013 infecting Sepia novaehollandiae (26\%). Medium prevalence (34-66\%) was recorded for Dicyemennea spencerense Catalano, 2013 infecting S. apama (54\%) and Dicyema furuyi Catalano, 2013 infecting S. papuensis (57\%). The remaining dicyemid species were all recorded to infect their respective cephalopod hosts with a high prevalence (Table 1). Although Dicyema koinonum, Dicyemennea spencerense and Dicyema furuyi were all recorded with a low or medium prevalence, the host species these dicyemids are recorded from are also infected by at least one other dicyemid species, which occurred at a high prevalence (Table 1). 
Table 2. Occurrence and percentage (in parentheses) of each renal appendage pattern of infection for each dicyemid species examined. See text for explanation of patterns of infection.

\begin{tabular}{|c|c|c|c|c|c|c|}
\hline \multirow[b]{2}{*}{ Dicyemid species } & \multirow[b]{2}{*}{ Cephalopod species } & \multirow[b]{2}{*}{$\begin{array}{l}\text { Number of host individu- } \\
\text { als examined }\end{array}$} & \multicolumn{4}{|c|}{$\begin{array}{l}\text { Pattern of infection } \\
\text { Number observed ( } \% \text { of total) }\end{array}$} \\
\hline & & & $\mathrm{A}$ & $\mathrm{B}$ & $\mathrm{C}$ & $\mathrm{D}$ \\
\hline Dicyema calamaroceum & Sepioteuthis australis & 2 & $0(0)$ & $0(0)$ & $1(50)$ & $1(50)$ \\
\hline Dicyema coffinense & Sepia apama & 7 & $3(43)$ & $0(0)$ & $3(43)$ & $1(14)$ \\
\hline Dicyema furuyi & Sepia papuensis & 4 & $2(50)$ & $0(0)$ & $0(0)$ & $2(50)$ \\
\hline Dicyema koinonum & Sepia apama & 29 & $5(17)$ & $1(3)$ & $18(62)$ & $5(17)$ \\
\hline Dicyema koinonum & Sepia novaehollandiae & 6 & $1(17)$ & $1(17)$ & $4(67)$ & $0(0)$ \\
\hline Dicyema multimegalum & Sepia apama & 3 & $0(0)$ & $0(0)$ & $0(0)$ & $3(100)$ \\
\hline Dicyema рарисеит & Sepia papuensis & 7 & $2(29)$ & $0(0)$ & $2(29)$ & $3(43)$ \\
\hline Dicyema pyjamaceum & Sepioloidea lineolata & 4 & $0(0)$ & $0(0)$ & $2(50)$ & $2(50)$ \\
\hline Dicyema vincentense & Sepia novaehollandiae & 13 & $1(8)$ & $0(0)$ & $5(38)$ & $7(54)$ \\
\hline Dicyemennea floscephalum & Octopus berrima & 22 & $1(5)$ & $0(0)$ & $20(91)$ & $1(5)$ \\
\hline Dicyemennea spencerense & Sepia apama & 14 & $5(36)$ & $1(7)$ & $4(29)$ & $4(29)$ \\
\hline \multirow[t]{2}{*}{ Dicyemennea spencerense } & Sepia novaehollandiae & 8 & $3(38)$ & $0(0)$ & $4(50)$ & $1(13)$ \\
\hline & TOTAL & 119 & $23(19)$ & $3(3)$ & $63(53)$ & $30(25)$ \\
\hline
\end{tabular}

\section{Variation in dicyemid fauna with host size}

All six cephalopod species except Sepioteuthis australis were sampled to their maximum achievable size (see Norman and Reid 2000, Reid et al. 2005 for maximum recorded ML of cephalopods). Sepioteuthis australis reaches a ML of up to $50 \mathrm{~cm}$ (Norman and Reid 2000), but was only sampled to $20.5 \mathrm{~cm}$ in this study. Dicyema calamaroceum, the single dicyemid species infecting this host cephalopod, was generally found in smaller individuals (Fig. 2F), although larger S. australis individuals will need to be collected to examine trends across the complete breadth of the host species size range.

In general, for cephalopod species infected by more than one dicyemid species, restriction to different size groups by each dicyemid species was observed (Fig. 2A-C). For Dicyemennea floscephalum Catalano, 2013 infecting Octopus berrima and Dicyema pyjamaceum Catalano et Furuya, 2013 infecting Sepioloidea lineolata, each dicyemid species was recorded across the complete ML range sampled, with no host individual found to be uninfected (Fig. 2D,E). Although cephalopod individuals were sampled to their maximum achievable size, some size groups were represented by only one or a few individuals, and for Sepia apama, S. papuensis and Sepioloidea lineolata, not all size groups were sampled (Fig. 2).

\section{Exploring the patterns of infection in renal appendages}

Four patterns of renal appendage infection were noted: pattern A, infection by both stages in both renal appendages (asexual and sexual stages in left and right renal appendages of the same host individual); pattern $\mathrm{B}$, infection by one stage in one renal appendage and the other stage in the other renal appendage (asexual stages only in left/right renal appendage, sexual stages only in right/ left renal appendage of the same host individual); pattern
$\mathrm{C}$, infection by the same stage in both renal appendages (only asexual stages in left and right renal appendages of the same host individual, or only sexual stages in left and right renal appendages of the same host individual); pattern $\mathrm{D}$, infection by one stage in one renal appendage and both stages in the other renal appendage (asexual stage in left renal appendage, sexual stage in left and right renal appendage of the same host individual, or sexual stage in left renal appendage, asexual stage in left and right renal appendage of the same host individual. Vice versa for right renal appendage of the same host individual) (Table 2). Pattern $\mathrm{C}$ was the most common, observed in over half the host individuals examined (63 of 119 host individual, see Table 2), whereas pattern B was rarely observed ( 3 of 119 host individuals, see Table 2). Patterns of infection also varied between dicyemid species. For some species, only one pattern was observed (i.e. Dicyema multimegalum Catalano, 2013 infecting S. apama displayed only pattern D), whereas for other species, all four patterns were recorded (i.e. D. koinonum and Dicyemennea spencerense infecting S. apama) (Table 2). However, this is likely influenced by the number and age/size of host individuals examined, rather than indicating real trends within dicyemid species.

Due to initial trials with fixing and staining methods (which resulted in uncertainty in differentiating asexual versus sexual stages), or bursting of the ink sac during dissections (which resulted in collection of only one renal appendage), renal appendage comparisons for some host individuals could not be undertaken (i.e. for 1 Sepioloidea lineolata, 2 Sepia novaehollandiae, 4 Sepioteuthis australis and 7 Sepia apama individuals). Subsequently, these individuals were not included in comparisons. As only one Octopus kaurna individual was collected, renal appendage comparisons were not performed for this host species. 


\section{DISCUSSION}

\section{Trends across host taxa}

In our study, 10 Southern Hemisphere cephalopod species in six different families were examined for dicyemid parasites. Variation was observed in the number of dicyemid species infecting taxa within each family, as well as variation in dicyemid prevalence among taxa. Our observations generally agree with those reported in the literature, as dicyemids have been described from Northern Hemisphere cephalopods in all six cephalopod families we sampled except Ommastrephidae (see Hochberg 1982, 1990, Catalano 2012). For this family in Northern Hemisphere studies, instead of dicyemids, chromidinid ciliates have been documented. These ciliates are the second most frequently encountered parasites in the renal appendages of benthic cephalopods after dicyemids (Hochberg 1982), although no ciliate was found from the single ommastrephid taxon in our study.

In our study, dicyemid species were recorded from Dicyema and Dicyemennea, two of the nine genera in Dicyemidae van Beneden, 1876 that combined, contain more than $90 \%$ (111 out of 122) of the presently described dicyemid species (Catalano 2012). The remaining seven genera in Dicyemidae have only been recorded from Northern Hemisphere cephalopods, except for Kantharella Czaker, 1994, which is documented from a single individual in Octopodidae collected from Antarctica, although the validity of this genus is uncertain (Furuya et al. 2007).

\section{Uninfected cephalopod species: a closer examination}

Hochberg (1990) and Furuya and Tsuneki (2005) propose that dicyemid parasites only infect benthic or epibenthic cephalopods, with initial infection occurring after hatching for hosts with demersal juveniles, or following settlement to the bottom for hosts with planktonic larval stages. Restriction of infection to benthic or epibenthic cephalopods is further supported by properties of the dispersive infusoriform embryo, which infects the new host individual. These dispersive embryos have large refringent bodies composed of highly hydrated magnesium salt of inositol hexaphosphate a chemical that provides the infective stage with negative buoyancy (Lapan 1975). In vitro, infusoriform embryos have been observed actively swimming at the bottom of a dish and it is therefore suggested that the role of this chemical is to help the embryo remain near the sea floor where it can encounter a new host individual (McConnaughey 1951, Lapan 1975). In our study, no dicyemid parasite was recorded from Euprymna tasmanica (Sepiolidae), Nototodarus gouldi (Ommastrephidae) and Metasepia pfefferi (Sepiidae), although these three cephalopod species have benthic stages in their life cycle.

For the southern dumpling squid, E. tasmanica, no dicyemid parasite was recorded from six host individuals, although dicyemids have been recorded previously from Northern Hemisphere Sepiolidae species in Rondeletiola Naef, Rossia, Sepietta Naef and Sepiola Leach (see Catalano 2012). Euprymna tasmanica frequently associates with the sea bottom, burying itself in the sand during the day to hide from predators (Norman and Reid 2000). Such a strategy appears to offer an ideal opportunity for infection by the infusoriform embryo, with dicyemids being recorded from the striped pyjama squid, Sepioloidea lineolata, which also employs this strategy and buries in the sand (infection in 5 of 5 hosts examined, see Table 1). Additionally in their study, Finn et al. (2005) recorded the presence of dicyemids in 14 out of $18 \mathrm{E}$. tasmanica individuals, including infections in hosts collected from the same locality as our study, Spencer Gulf, South Australia. Therefore, other factors rather than host phylogeny, host behaviour and geographical locality may be influencing presence of infection.

One such factor may be host size. Euprymna tasmanica reaches $7 \mathrm{~cm}$ ML (Norman and Reid 2000). However, individuals examined did not exceed $3.2 \mathrm{~cm}$ ML in our study (Table 1). Host size ranges and prevalence of infection are not provided in the studies that describe dicyemids from Northern Hemisphere Sepiolidae species (van Beneden 1876, Whitman 1883, Nouvel 1944, 1947, Bogolepova-Dobrokhotova 1960, 1962, 1963, Hoffman 1965). However, Furuya et al. (1992) and CastellanosMartinez et al. (2011) did not record dicyemid parasites in small Octopus vulgaris Cuvier and O. hubbsorum Berry individuals in their respective studies, nor did Furuya and Tsuneki (2005) for small individuals of the bigfin reef squid, Sepioteuthis lessoniana Lesson. They suggest that in general, smaller host individuals do not harbor dicyemids. This can be correlated to renal appendage complexity, with larger individuals having more complex external surfaces than smaller host individuals, thus providing more attachment sites and surface area for vermiform stages (Furuya et al. 2004).

While the red arrow squid, Nototodarus gouldi, is classified as an oceanic species, with adults spending most of their lives offshore on the continental shelf at depths between 50-200 $\mathrm{m}$, the larval and juvenile stages are found in shallow coastal waters to the sea bottom (Norman and Reid 2000, Triantafillos et al. 2004). Therefore, variation in habitat type could allow for infection by the infusoriform embryo to be established early on before this host species shifts to oceanic waters. However, all three $N$. gouldi individuals collected from Spencer Gulf and Gulf St Vincent, South Australia, were uninfected. No prior study has examined this host species for dicyemids, and only chromidinid ciliates have been recorded from Northern Hemisphere taxa in Ommastrephidae. Nonetheless, dicyemids have been reported from three other Northern Hemisphere oceanic squid species (Loliginidae) but with low prevalence: Sepioteuthis lessoniana, 71 of 113 individuals $(63 \%)$ infected by two dicyemid species 
(Nouvel and Nakao 1938, Furuya and Tsuneki 2005), Loligo sp., 2 of 32 individuals (6\%) infected by one dicyemid species (Kalavati and Narasimhamurti 1980), and L. duvauceli d'Orbigny, 8 of 26 individuals (31\%) infected by one dicyemid species (Kalavati et al. 1984). The Southern Hemisphere Australian squid species, Sepioteuthis australis (Loliginidae), was also found to be infected with a low prevalence by one dicyemid species in our study ( 6 of 25 individuals infected, i.e. $24 \%$; see Table 1), but uninfected in the study by Finn et al. (2005) for 11 S. australis individuals examined. In general, even though benthic stages may exist, oceanic squid species in the Northern and Southern Hemisphere seem to share a pattern of low dicyemid intensity of infection, which could correlate to life history properties.

Pfeffer's flamboyant cuttlefish, Metasepia pfefferi, is a small species reaching about $8 \mathrm{~cm}$ ML. It is known to wander around the sea bottom during the day (Norman and Reid 2000), which would provide an ideal opportunity for infection by the infusoriform embryo. Two $M . p f-$ efferi individuals collected from one locality in our study were both uninfected, although other taxa in Sepiidae collected from the Northern and Southern Hemisphere are infected by dicyemids (see Finn et al. 2005, Catalano 2012). Nonetheless, ours is the first study to examine a Metasepia species for dicyemids, and due to low sample size, infection may have been undetected especially if factors such as host size and geographical locality are important determinants of infection in this host species.

\section{Exploring patterns of dicyemid fauna composition and prevalence}

Furuya and Tsuneki (2005) suggested that there is a direct relationship between host size and dicyemid occurrence. Generally, smaller host individuals do not harbour dicyemids, although this depends on the species of cephalopod. However, this could be attributed to sampling bias, as smaller individuals may not be captured and subsequently examined as frequently as larger individuals, thus resultant host size patterns may be misconceived. Dicyemid parasite prevalence may also be low in small host individuals as it may take time for colonisation of the renal appendage to reach a peak, meaning detection probability is low in small-sized individuals compared to large-sized individuals that have been infected for longer periods of time.

For the three host species infected by multiple dicyemid species, restriction to different size groups by each dicyemid species was generally observed with different prevalences by each species (Fig. 2A-C). Sepia apama was found to be infected by four dicyemid species, with Dicyema koinonum, D. coffinense Catalano, 2013 and Dicyemennea spencerense recorded from small sized individuals with different prevalence of infection $(97 \%$, $73 \%$ and $54 \%$, respectively) and Dicyema multimegalum recorded from large-sized individuals with $75 \%$ preva- lence (Fig. 2A, Table 1). All four species were not found to co-occur in one host individual, with co-occurrence occasionally observed for two dicyemid species in one host individual (Catalano 2013b). For S. novaehollandiae, D. koinonum was documented with low prevalence across all size groups, whereas D. vincentense Catalano, 2013 was only found in medium-sized individuals and Dicyemennea spencerense in large-sized individuals, both with high prevalence (Fig. 2B, Table 1). Again, all three dicyemid species were not found together within one host individual, although two dicyemid species in one host individual was observed (Catalano 2013b). Lastly, for S. papuensis, Dicyema papuceum Catalano, 2013 was found across the sampled size range with high prevalence, whereas $D$. furuyi was only documented in medium- to large-sized individuals with medium prevalence (Fig. 2C, Table 1). Both dicyemid species were found to co-occur in four host individuals (Catalano 2013a).

Competition may be responsible for our observation of restriction to certain size groups when there is infection by multiple species compared with infection across the sampled size range when there is only infection by one dicyemid species. For infection by multiple dicyemid species, restriction to certain size groups may allow each species to occupy its own niche in an effort to minimise competition for factors such as space, nutrients and attachment site. Different prevalence when there is infection by multiple dicyemid species may also indicate dominance of certain species over others. Those that were recorded with high prevalence may have established in the renal appendages first or be better adapted to the host species (by shape of calotte, evasion of the host immune response, acquisition of nutrients, etc.) than those recorded with low prevalence. Furuya (2006) agrees, stating that the dominant dicyemid species with the highest prevalence is best adapted to the habitat provided by that host. Nonetheless, all size groups for S. apama, S. papuensis and Sepioloidea lineolata were not sampled and some size groups were represented by one or only a few individuals, so patterns of infection by host size explored here should be treated tentatively.

Factors such as geographical collection locality may also influence observed restriction patterns of dicyemid species to certain size groups. For example, Furuya and Tsuneki (2005) reported dicyemids in small host individuals of Sepioteuthis lessoniana at Uozu, Sakaiminato and Mihonoseki (Sea of Japan), but not from Minabe (Pacific Ocean) and Akashi (Inland Sea). At Okinawa (Ryukyu Islands), no dicyemid was recorded from large host individuals. Other studies also attribute occurrence patterns of different dicyemid species within a single host species to geographical collection locality of host individuals rather than host size (Furuya 2008). In our study, both Sepia apama and S. novaehollandiae were collected from multiple localities in Australian waters. Although Dicyema multimegalum was only recorded in larger host individu- 
als, it was also only recorded in hosts collected from New South Wales, which happen to be the largest $S$. apama individuals sampled for this species. Furthermore, D. coffinense was restricted to Coffin Bay, D. koinonum to Spencer Gulf (SG) and Gulf St Vincent (GSV) and Dicyemennea spencerense to SG, despite similar-sized host individuals occurring in all these localities. The same is true for $S$. novaehollandiae, with Dicyema koinonum restricted to SG and GSV, D. vincentense to GSV and Dicyemennea spencerense to SG. Therefore, for these two cuttlefish species, geographical collection locality of host individuals, rather than host size, appears to be the factor responsible for the observed dicyemid fauna composition.

\section{Exploring the patterns of infection in renal appendages}

The kidneys of cephalopods consist of a pair of sac-like renal organs, which each contain a renal appendage. The majority of past studies investigating dicyemid infections treat the renal appendages as a single entity. Therefore, patterns of infection and differences between renal appendages, which may provide an insight into cues responsible for dicyemid maturation, cannot be evaluated. For the few studies that have examined the renal appendages as separate entities, host taxa have been restricted to Octopodidae and patterns of infection reported are generally between dicyemid species in each renal appendage, rather than reproductive stages in each renal appendage. For example, Furuya $(2006,2008)$ recorded different dicyemid species in the left compared to the right renal appendage for $8 \%$ of Amphioctopus fangsiao d'Orbigny individuals (40 of 506) and 31\% of Octopus sasakii Taki individuals (18 of 59), respectively.

In our study, the most common pattern observed was infection by the same stage (either asexual or sexual) in both renal appendages of a host individual (pattern C, Table 2). However, for one $S$. apama (14.5 cm ML) and one $S$. novaehollandiae (10.5 cm ML) individual, asexual stages of Dicyema koinonum were exclusively observed in one renal appendage whereas sexual stages were exclusively observed in the other renal appendage. The same was observed for Dicyemennea spencerense infecting S. apama: in one host individual (14.5 cm ML), different stages were observed in each renal appendage (pattern B, Table 2). Based on variable ML of host individuals, size does not appear to be a factor responsible for observation of this rare infection pattern. As this pattern was recorded for two dicyemid species in two genera, this suggests the mechanism responsible is not dicyemid-species specific. Furthermore, the observation of four patterns, including exclusive infection by asexual stages in one appendage and sexual stages in the other, suggests that dicyemids may infect the renal appendages independent of one another and potentially at different times. These patterns also suggest that dicyemid individuals infecting one side of the renal appendage do not or are unable to move to the other side. If dicyemids could move between renal appendages, the same stages should be found on both sides, and therefore patterns B and D would not have been detected.

Previous authors have observed sexual dicyemid stages in only sexually mature hosts and therefore suggest that the cue which triggers the transition from one life cycle stage to the other is host mediated, with cues relating to hormone fluxes associated with host maturation (see Hochberg 1983). However, Lapan and Morowitz (1975) showed, via an experimental approach, that a change in stages can be correlated to population density of dicyemids in the renal appendages. They suggested that when a maximum density is reached within the renal appendage, such that space and nutrients may become limited, a change in life stages occurs and the dicyemid strategy shifts from population increase to production of the infusoriform embryos for dispersal. Furthermore, they proposed that the shift from asexual reproduction and increasing density strategies to sexual reproduction and dispersal strategies may be mediated via chemical or mechanical cues from the dicyemids rather than being host mediated (Lapan and Morowitz 1972).

Finn et al. (2005) also recorded different stages of dicyemid infections in the renal appendages within single octopus individuals (Hapalochlaena maculosa Hoyle), with nematogens in the left renal appendage and rhombogens in the right renal appendage. Based on observing this same pattern of infection here from two cuttlefish species with different dicyemid stages in left versus right renal appendages, we agree with Lapan and Morowitz (1975) and Finn et al. (2005) that the developmental cues mediating the transition from the asexual to sexual stages is parasite-mediated. This cue also appears to be controlled independently and in isolation within each renal appendage. If this process was host-mediated, by hormone fluxes in correlation to host maturation, it would be expected that both renal appendages were equally affected and the same dicyemid stage (asexual and sexual) should be observed in both appendages.

\section{When and how does new infection occur?}

If the infusoriform embryo is released from a host individual, sinks to the sea bottom, but does not infect small/ young host individuals or those at certain geographical localities, then when and how does new dicyemid infection of hosts occur? These parasites are highly host specific, so the infusoriform embryo must also find and infect the correct cephalopod species for the life cycle to continue. In addition, McConnaughey (1951) observed the behaviour of escaped infusoriform embryos and found that after $12 \mathrm{~h}$ in seawater, many had undergone general disaggregation and after three to four days, none was alive. This leaves an even smaller window of opportunity for 
a new host individual with the correct size requirements, species-specificity, geographical location and position in the benthos to be found and infected by the infusoriform embryo. It may be that small and young host individuals are infected, with the embryo or released cells lying dormant or residing in another organ until such a time that the surface of the renal appendage becomes complex and will support infection by vermiform stages.

Hoffman (1965) and Furuya (2007) have recorded Dicyemennea brevicephaloides Bogolepova-Dobrokhotova, 1962 from the branchial heart appendages and surrounding coelomic cavities of Rossia pacifica Berry. However, we consider these sites to be an exit rather than entry point for the infusoriform embryo into the sea. A route survey would therefore be enlightening to evaluate if dicyemids occur in other organs in young or small cephalopods, then move to the renal appendages as the cephalopod matures and grows, and finally to the branchial heart appendage and coelomic cavities for escape. Whatever the route, considering the challenges the microscopic infusoriform embryo must face to find and infect a new host individual, it is astonishing that most cephalopods are found to be infected by dicyemid parasites at such high intensities.

\section{The way forward for future dicyemid studies}

Additional thorough and broad-scale taxonomic studies on dicyemids that encompass appropriate sample sizes of multiple host taxa and host individuals within each taxon are needed to further evaluate dicyemid occurrence patterns in relation to host size, host geographical collection locality and host life history strategies. Furthermore, to confirm patterns of infection between renal appendages by developmental stages observed in the present study, we advocate other investigators in the future to also examine each renal appendage independently. Collectively this will allow a greater global understanding of dicyemid patterns of infection and host specificity. Coupled with classical taxonomic methods, modern molecular approaches should be explored in current day research that focuses on dicyemid parasites. These new molecular advances and technologies may allow greater sensitivity in detecting parasite taxa and could also help resolve the unknown questions surrounding the dicyemid life cycle and the phylum's position in the Tree of Life.

Acknowledgements. Thanks are due to Dave Barker, Kieran Brazell, Cameron Dixon, Kathleen Hill, Graham Hooper, Kate Hutson, Bernadette Saunders, Brian Saunders, Richard Saunders, Alex Schnell and Errol Sporer for assistance with cephalopod collections and organising research trawl survey trips. All research was conducted with approval from the University of Adelaide Animal Ethics Committee (No. S-2010-116) and according to Primary Industries and Resources SA S115 Ministerial Exemptions (No. 9902264 and No. 9902398). Funding for this project has been provided by the Australian Society for Parasitology, Norman Wettenhall Foundation, Holsworth Wildlife Research Endowment, Sir Mark Mitchell Research Foundation, Lirabenda Endowment Fund, Nature Foundation South Australia, Nature Conservation Society of South Australia and Australian Federation of University Women South Australia. The authors are grateful to Tim Benson for his continual support. SRC is funded by an Australian Postgraduate Award and BMG by an ARC Future Fellowship (FT100100767).

\section{REFERENCES}

Bogolepova-Dobrokhotova I.I. 1960: [Dicyemidae of fareastern seas I. New species of the genus Dicyema.] Zool. Zh. 39: 1293-1302. (In Russian.)

Bogolepova-DoвROKнотоVA I.I. 1962: [Dicyemidae of fareastern seas II. New species of the genus Dicyemennea.] Zool. Zh. 41: 503-518. (In Russian.)

Bogolepova-DoвRокнотоva I.I. 1963: [The current classification of dicyemids.] Parazitol. Sb. 21: 259-271. (In Russian.)

Castellanos-Martinez S., Gomez M.C., Hochberg F.G., Gestal C., Furuya H. 2011: A new dicyemid from Octopus hubbsorum (Mollusca: Cephalopoda: Octopoda). J. Parasitol. 97: $265-269$.

Catalano S.R. 2012: A review of the families, genera and species of Dicyemida van Beneden, 1876. Zootaxa 3479: 1-32.

Catalano S.R. 2013a: First descriptions of dicyemid mesozoans (Dicyemida: Dicyemidae) from Australian octopus (Octopodidae) and cuttlefish (Sepiidae) species, including a new record of Dicyemennea in Australian waters. Folia. Parasitol. 60: 306-320.

Catalano S.R. 2013b: Five new species of dicyemid mesozoans (Dicyemida: Dicyemidae) from two Australian cuttlefish species, with comments on dicyemid fauna composition. Syst. Parasitol. 86: 125-151.
Catalano S.R., Furuya H. 2013: Two new species of dicyemid (Dicyemida: Dicyemidae) from two Australian cephalopod species: Sepioteuthis australis (Mollusca: Cephalopoda: Loliginidae) and Sepioloidea lineolata (Mollusca: Cephalopoda: Sepiadariidae). J. Parasitol. 99: 203-211.

Combes C. 1997: Fitness of parasites: pathology and selection. Int. J. Parasitol. 27: 1-10

Finn J.K., Hochberg F.G., Norman M.D. 2005: Phylum Dicyemida in Australian waters: first record and distribution across diverse cephalopod hosts. Phuket Mar. Biol. Cent. Res. Bull. 66: 83-96.

FURUYA H. 1999: Fourteen new species of dicyemid mesozoans from six Japanese cephalopods, with comments on host specificity. Spec. Div. 4: 257-319.

FURUYA H. 2006: Three new species of dicyemid mesozoans (Phylum Dicyemida) from Amphioctopus fangsiao (Mollusca: Cephalopoda), with comments on the occurrence patterns of dicyemids. Zool. Sci. 23: 105-119.

FURUYA H. 2007: Redescription of two Dicyemennea (phylum: Dicyemida) from Rossia pacifica (Mollusca: Cephalopoda: Decapoda). J. Parasitol. 93: 841-849.

FuruYa H. 2008: Three new dicyemids from Octopus sasakii (Mollusca: Cephalopoda: Octopoda). J. Parasitol. 94: 10711081. 
Furuya H., Hochberg F.G., Tsuneki K. 2003: Reproductive traits in dicyemids. Mar. Biol. 142: 693-706.

Furuya H., Hochberg F.G., Tsuneki K. 2007: Cell number and cellular composition in vermiform larvae of dicyemid mesozoans. J. Zool. 272: 284-298.

Furuya H., Ota M., Kimura R., Tsuneki K. 2004: Renal organs of cephalopods: A habitat for dicyemids and chromidinids. J. Morphol. 262: 629-643.

Furuya H., TsuneKi K. 2003: Biology of dicyemid mesozoans. Zool. Sci. 20: 519-532.

Furuya H., Tsuneki K. 2005: A new species of dicyemid mesozoan (Dicyemida: Dicyemidae) from Sepioteuthis lessoniana (Mollusca: Cephalopoda), with notes on Dicyema orientale. Spec. Div. 10: 45-62.

Furuya H., Tsuneki K., Koshida Y. 1992: Two new species of the genus Dicyema (Mesozoa) from octopuses of Japan with notes on D. misakiense and D. acuticephalum. Zool. Sci. 9: 423-437.

HochBerG F.G. 1982: The "kidneys" of cephalopods: a unique habitat for parasites. Malacologia 23: 121-134.

HochBeRG F.G. 1983: The parasites of cephalopods: a review. Mem. Nat. Mus. Vict. 44: 108-145.

Hochberg F.G. 1990: Diseases caused by protists and mesozoans. In: O. Kinne (Ed.), Diseases of Marine Animals. Vol. 3. Biologische Anstalt Helgoland, Hamburg, pp. 47-202.

Hoffman E.G. 1965: Mesozoa of the sepiolid, Rossia pacifics (Berry). J. Parasitol. 51: 313-320.

Kalavati C., Narasimhamurti C.C. 1980: A new dicyemid mesozoan, Dodecadicyema loligoi n. gen., n. sp. from the renal appendages of Loligo sp. Proc. Indian Acad. Sci. (Anim. Sci.) 89: 287-292.

Kalavati C., Narasimhamurti C.C., Suseela T. 1984: Four new species of mesozoan parasites (Mesozoa: Dicyemidae) from cephalopods of Bay of Bengal. Proc. Indian Acad. Sci. (Anim. Sci.) 93: 639-654.

LAPAN E.A. 1975: Magnesium inositol hexaphospate deposits in mesozoan dispersal larvae. Exp. Cell Res. 94: 277-282.

Lapan E.A., Morowitz H.J. 1972: The Mesozoa. Sci. Am. 227: 94-101.

Lapan E.A., Morowitz H.J. 1975: The dicyemid Mesozoa as an integrated system for morphogenetic studies. J. Exp. Zool. 193: $147-160$.

McConnaughey B.H. 1951: The life cycle of the dicyemid Mesozoa. Univ. Calif. Publ. Zool. 55: 295-336.

Received 20 November 2013
Norman M., Reid A.L. 2000: A Guide to Squid, Cuttlefish and Octopuses of Australasia. CSIRO Publishing, Collingswood, Victoria, 96 pp.

Norman M., Sweeney M.J. 1997: The shallow-water octopuses (Cephalopoda: Octopodidae) of the Philippines. Invertebr. Taxon. 11: 89-140.

Nouvel H. 1944: Les dicyémides des Sepiolidae des côtes françaises. Bull. Inst. Océanograph. 869: 1-12.

Nouvel H. 1947: Les dicyémides I. Systématique, générations vermiformes, infusorigène et sexualité. Arch. Biol. 58: 59-214.

Nouvel H., Nakao Y. 1938: Dicyémides du Japon. Bull. Soc. Zool. France 63: 72-80.

Reid A., Jereb P., Roper C.F.E 2005: Family Sepiidae. In: P. Jereb and C.F.E. Roper (Eds.), Cephalopods of the World: An Annotated and Illustrated Catalogue of Species Known to Date. Vol. 1. Chambered Nautiluses and Sepioids (Nautilidae, Sepiidae, Sepiolidae, Sepiadariidae, Idiosepiidae and Spirulidae). FAO, Rome, pp. 57-152.

Roberts M.G., Dobson A.P., Arneberg P., De Leo G.A., Krecek R.C., Manfredi M.T., Lanfranchi P., ZafFARONI E. 2002: Chapter 4: Parasite Community Ecology and Biodiversity. In: P.J. Hudson, A. Rizzoli, B.T. Grenfell and H. Heesterbeek (Eds.), The Ecology of Wildlife Diseases. Oxford University Press, New York, pp. 63-82.

Semmens J.M., Pecl G.T., Gillanders B.M., Waluda C.M., Shea E.K., Jouffre D., Ichit T., Zumholz K., Katugin O.N., Leporati S.C., Shaw P.W. 2007: Approaches to resolving cephalopod movement and migration patterns. Rev. Fish Biol. Fisher. 17: 401-423.

Triantafillos L., Jackson G.D., Adams M., McGrathSteer B.L. 2004: An allozyme investigation of the stock structure of arrow squid Nototodarus gouldi (Cephalopoda: Ommastrephidae) from Australia. J. Mar. Sci. 61: 829-835.

van BenEDen E. 1876: Recherches sur les Dicyemides, survivants actuels d'un embranchement des Mésozoaires. Bull. l'Acad. Roy. Sci. Let. Bruxelles 41: 1160-1205.

Whitman C.O. 1883: A contribution to the embryology, lifehistory and classification of the dicyemids. Mitt. Zool. Stat. Neapel 4: 1-90.

Whittington I.D., CribB B.W., Hamwood T.E., Halliday J.A. 2000: Host-specificity of monogenean (platyhelminth) parasites: a role for anterior adhesive areas? Int. J. Parasitol. 30: 305-320.

Accepted 29 January 2014 